\title{
At forlade sekten
}

\section{Afhoppernes bekendelser}

\section{Indledning}

Yusuf Zaydans Azazil (2008) og Khalid al-Barris Verden er skønnere end Paradiset (2001) er to interessante bøger fra den nye arabiske litteratur, som begge har affødt debat og diskussion af forskelligt omfang. Begge har den religiøse fundamentalisme som tema og er skrevet ud fra afhopperens glemte perspektiv. En opdigtet kristen munk fra 400-tallet og en nutidig og faktisk eksisterende islamisk ungdomsaktivist fortæller samme slags historie: hvordan de blev draget ind i den religiøse sekt og hvordan det siden, efter mange kvaler, lykkedes for dem at bryde ud. Den personlige bekendelse er et forenende bånd mellem teksterne, hvis handlinger fortælles i jeg-form, skønt den ene bog er en spændende historisk roman i skikkelse af en selvbiografi og den anden er en journalistisk skrevet ægte levnedshistorie. Genremæssigt repræsenterer teksterne tilsyneladende uforenelige sider af litteraturen: den strenge dokumentar og den rene fantasi, fakta og fiktion - lige så definitivt og radikalt adskilte som to sider på en mønt. Alligevel, præcis som med mønten, hænger de sammen og danner et hele. Den verden og virkelighedsproblematik, de refererer til, er nemlig fælles: den aktuelle politisering af islam og voldsudøvelsen i Guds navn.

Forfatterne kommer begge fra Egypten, men læses også flittigt uden for landets grænser. Azazil følger en lang egyptisk tradition for historiske romaner, i hvilke den politiske allegori er tydelig. Takket være sin historiske detaljerigdom og veludførte illusion af autenticitet, sit tema og sin tendens, er bogen blevet en bestseller og har vundet priser. Den repræsenterer, mener jeg, en ny trend i den samtidige arabiske litteratur, hvor grænsen mellem populærlitteratur og seriøs litteratur igen er blevet mere flydende, og læsningen i visse befolkningsgrupper er øget. Verden er skønnere end Paradiset udkom først som føljeton i pressen (i Libanon) og følger dermed også et veletableret mønster i den arabiske prosalitteratur. Men nogen kioskbasker er bogen ikke blevet og bliver det næppe; dertil er den alt for kortfattet og måske også alt for ærlig og kontroversiel. 


\section{På Djævlens ordre}

Årets (2009) vinder af den såkaldte arabiske Booker-pris blev en historisk roman, som handler om de sekteriske stridigheder i den tidlige kristendom. Prisens officielle navn er "Den internationale pris for arabisk skønlitteratur" (www.arabicfiction.org), og den blev i år uddelt for anden gang. Forfatteren til vinderromanen, Azazil, er egypteren Yusuf Zaydan, tidligere helt ukendt i litterære sammenhænge. ${ }^{\mathrm{I}}$ Udmærkelsen kom derfor som en stor overraskelse for de fleste inden for den arabiske litterære offentlighed og affødte straks voldsom debat: Hvordan, undrede man sig, kunne en nybegynder slå fuldblodsproffer som Muhammad al-Bisati, Ibrahim Nasrallah og andre kandidater, som også stod på den korte liste? Læg dertil at emnet for vinderbogen var religion og at muslimen Zaydan dristede sig til at skrive om kristendommen med teologiske prætentioner, og lunten var tændt!

Hovedpersonen i Azazil, et af djævlens mange navne på arabisk, er en egyptisk munk i 400-tallet. ${ }^{2}$ På tredive ark pergament nedskriver munken sin livshistorie, lægger arkene i en kiste og graver den ned i det kloster i Syrien, hvor han opholder sig. Mere end 1500 år senere bliver kisten fundet af en arkæolog under udgravninger af ruinbyerne nord for Aleppo. En navnløs oversætter støder på en eller anden måde på fundet og bruger siden omkring syv år på at oversætte munkens historie fra syrisk (aramæisk) til arabisk. Derefter offentliggør han sit værk sammen med et forord, som stipulerer, at teksten ikke må trykkes før efter hans død.

Romanen er med andre ord konstrueret som en fiktiv selvbiografi præsenteret som en fiktiv oversættelse; der findes en handling og en rammehandling, og både forfatteren og oversætteren er ifølge fiktionen døde. Bogen lader som om, den er et autentisk historisk dokument. Den leger med det antikke artefakts karakteristika. Min udgave af romanen (femte oplag) indeholder eksempelvis et appendiks med billeder af antikke portrætter, mosaikker og ruiner, som påstås at forestille de personer og pladser, som figurerer i munkens livshistorie. ${ }^{3}$ At den faktiske forfatter, Yusuf Zaydan, er chef for håndskriftsafdelingen på Biblioteket i Alexandria (Bibliotheca Alexandrina) og besidder stor historisk sagkundskab er ikke uvæsentligt at vide i sammenhængen.

Intrigen i Azazil bygger på skismaet mellem de forskellige kristne kirker i løbet af 300- og 400-tallet, som havde grund i seje teologiske konflikter omkring Kristi natur. Ifølge én opfattelse var Jesus på samme tid både gud og menneske i en uadskillelig enhed, ifølge en anden var Jesus' menneskelige natur tydeligt adskilt fra hans guddommelige manifestation. De forskellige dogmer repræsenteredes af forskellige biskopper i datidens kristendom, som havde sit centrum i den østlige del af Middelhavsområdet. Efter kejser Konstantin den Stores overgang til kristendommen samt ophøjelse af denne til statsreligion i Romerriget kom politikken med som en vigtig faktor i striden. Forskellige lande valgte forskellig teologi, delvis afhængigt af lokale magtambitioner hos kirken. Med tiden blev denne splittet i forskellige geografisk baserede samfund: den byzantiske kirke, “Østens kirke” (i Mesopotamien), den syriske kirke, den koptiske kirke - med flere.

Hovedpersonen, munken Hiba, drages ind i striden. I Alexandria møder han biskop Kyrillus, den koptiske kirkes fader, der fremstilles som en religiøs ekstremist, voldsprædikant og magtmenneske, som ophidser de troende til mord og forfølgelse 
af hedningerne. ${ }^{4}$ I Jerusalem møder han biskop Nestorius, som fremstilles som en fredens mand og den religiøse tolerances fortaler, men også som en stædig person som ikke er parat til at forhandle med sin tro. Den førstnævnte prædiker, at Maria fødte en Gud, hun er "gudsføderske", den sidstnævnte, at hun fødte et menneske og er "kristusføderske". Og begge erklærer modstanderen for kætter.

I det fiktive manuskript på de tredive pergamentblade kæmper Hiba med dette teologiske problem (og læner sig i Nestorius' retning), men grubler endnu mere over konsekvenserne af den religiøse vold på jorden. Hans personlige historie er grum, og han er selv et offer. Som barn ser han sin far blive myrdet af kristne fanatikere foran et egyptisk tempel ved Nilen, hvortil han er kommet for at aflevere sin fangst af fisk til de sidste tilbageværende hedenske præster. I Alexandria, hvor Hiba så småt begynder at studere medicin, begejstres han af filosoffen Hypatia og hendes offentlige forelæsninger, men chokeres stærkt da hun bliver lynchet af en kristen pøbel for øjnene af ham. Hvordan kan det være, at Jesu lære om fred på jorden fører til sådanne forfærdelige handlinger? Fuld af væmmelse og skræk flygter han fra byen, som styres af den dæmoniske Kyrillus. I sit indre opdager han også en anden dæmon: liderligheden og begæret. Han er blevet forført af en tjenestepige i Alexandria i løbet af tre hede dage, og tyve år efter lider han samvittighedskvaler for sine seksuelle udsvævelser, naturligvis i cølibat, indtil næste fristelse bringer ham til fald, en fattig korpige som han er blevet forelsket i. Efter denne sidste synd rammes han af høj feber, hallucinerer og ser Djævlen, Azazil, træde frem for sit blik. Azazil siger til ham, at han skal skrive sin historie uden at fortie noget, og Hiba hører det og adlyder...

\section{Politisk allegori}

Hvorfor blev denne fortælling belønnet med en af de allermest prestigefyldte litteraturpriser i den arabiske verden og med en prissum på sammenlagt 60.000 USD samt garanteret oversættelse til engelsk og international lancering som bonus? En mulig forklaring er den litterære form. Azazil er en spændende, letlæst og romantisk roman efter vanlig opskrift. Ingredienserne er stærke: heltemod og skurkagtighed, kærlighed og had, dyd og last, godhed og ondskab. Figurerne er tydeligt tegnede, naive eller lumske uden at udarte til skabeloner. Handlingen er (melo)dramatisk og miljøet eksotisk. Vovede sexscener blandes med blodige episoder. Munken er sympatisk, en ensom helt hvis længsel efter retfærdighed, stillen spørgsmålstegn ved lederne og personlige søgen det er let at identificere sig med. Sproget i romanen er ligefremt og ukompliceret, om end stedvist sentimentalt og affekteret.

Denne genre, eventyrromanen, traditionel og gammel som den er, repræsenterer samtidig en ny trend i den arabiske prosa: popularisering! Efter en lang periode med en voksende kløft mellem forfatter og læser og faldende oplag skimter vi nu fremvæksten af en arabisk bestsellerlitteratur. ${ }^{5}$ Den består af romaner, som henvender sig til et bredt publikum og er skrevet af nye forfattere, som tager afstand fra den litterære elitisme - og radikalisme - som har domineret den arabiske prosa lige siden 1960'erne. Bestsellerromaner som Yacoubians hus (2002) og Chicago (2007) af egypteren Alaa al-Aswany eller Pigerne fra Riyadh (2005) af Rajaa Alsanea fra 
Saudi Arabien er et helt nyt fænomen på det arabiske bogmarked. Pludselig synes der at være købsglade forbrugere og penge at tjene! Kommerciel er ikke længere et skældsord. Tværtimod markedsføres arabiske bøger nu ved hjælp af bestsellerlister og salgsstatistik, præcis som i Europa og USA. Disse lister er nye begivenheder i den arabiske verden. Globaliseringen og it-revolutionen har tydeligt forandret både læsernes efterspørgsel og markedets evne til at tilfredsstille den i mange lande. Måske er den litterære smag blevet mere global?

Uanset hvad er det ikke nogen vovet gisning, at dommerne til årets pris har skævet til publikumspotentialet hos den vindende roman. ${ }^{6}$ En bog som Azazil kombinerer elementer fra kvalitetslitteraturen og populærlitteraturen, seriøsitet med underholdning. I en oplysende kommentar efter vindertilkendegivelsen forklarede Jonathan Taylor, formand i Booker Prize Foundation og medlem af den styrende priskomité, at en tanke med udmærkelsen er "at løse paradokset bestseller - mesterværk ved at gøre det sidste til det første." Azazil er nu næppe et mesterværk i mine øjne, men allerede en lille bestseller på arabisk og muligvis så småt på andre sprog også.

Historiske fiktioner har længe været populære i arabisk litteratur og er ofte underholdende trods et alvorligt budskab. Nobelpristageren Mahfouz begyndte eksempelvis sin karriere i 1940'erne med tre romaner med faraoniske motiver, som på det allegoriske plan var nationalistiske moraliteter med anti-kolonial (læs: anti-britisk) tendens. Den moderne arabiske dramatiks fader, Tawfiq al-Hakim (1898-1987), protesterede i 1960'erne mildt, men tydeligt mod præsident Nassers udemokratiske, arabisk-socialistiske regime med et stykke om en rådvild sultan i middelalderen. Og så videre. ${ }^{8}$ Zaydans roman er også en politisk allegori, hvilket er en anden plausibel grund til dens udmærkelse. Men hvad siger denne allegori?

Det hede emne i romanen er naturligvis religion og politik. Ganske vist handler bogen om skismaerne inden for kristendommen, men scenen for dramaet er Mellemøsten og Nordafrika. I dag er denne region, hvor den implicitte læser bor, stedet for store modsætninger mellem forskellige tolkninger af islam, sekteriske splittelser og forfølgelse af utro og vantro både inden for og uden for det islamiske fællesskab. Historien går ligesom igen, dog på en anden måde. På det politiske plan er fjendtligheden mellem Egypten, Syrien, Tyrkiet m.fl. (Israel, ikke at forglemme) analog til splittelsen mellem landene dengang. Og fortidens stormagt repræsenteret af kejseren i Konstantinopel har med lidt fantasi også moderne paralleller.

Skal troende muslimer anvende vold for at opnå deres politiske og religiøse mål? - det er det tavse spørgsmål, som står skrevet med store bogstaver mellem linjerne. Zaydans svar er nej, og munken Hiba kommer til at illustrere afhopperens gode eksempel, den troende som følger sin samvittigheds lov i stedet for eksegeternes diktat. Nogle år i sin ungdom er han lydigt medlem af den kristne kirke i Alexandria og en af dens munke. Men forfølgelserne af anderledes tænkende og Jesus-fanatismen, som når en kulmination med mordet på den fredelige matematiker og filosof Hypatia, symbolet på kunst og videnskab, får helten til at flygte fra sekten, som senere skal blive til den egyptisk-ortodokse koptiske kirke. Moralen af Hibas livshistorie er kort sagt, at religionen bør være en privatsag og ikke en politisk ideologi. Og budskabet er rettet til dagens arabiske ungdom. Spørgsmålet er bare, om argumentet går ind? 


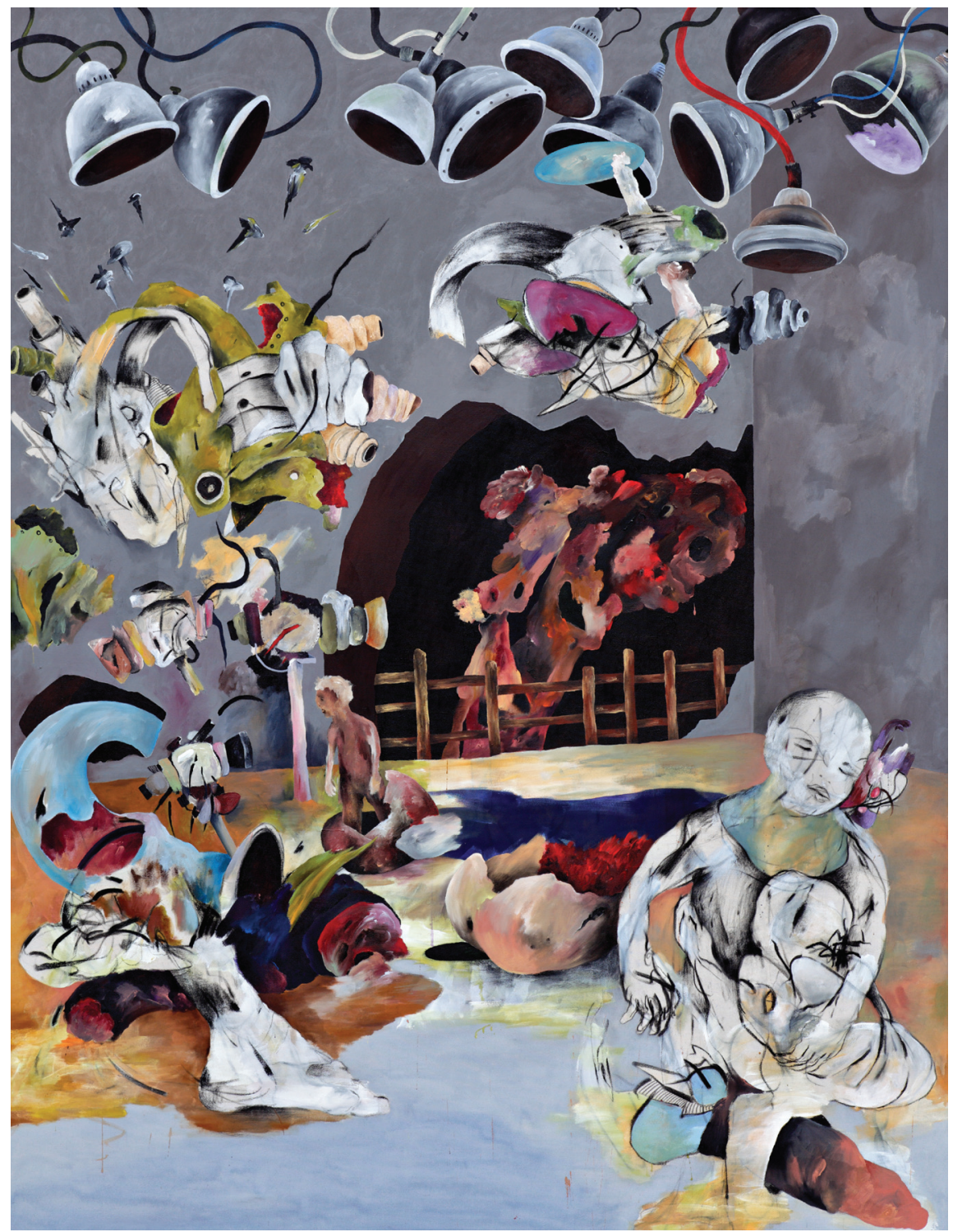

Ahmed Alsoudani: Untitled. Trækul, akryl og olie på lærred, 250 x 190 cm, 2009. (c) Ahmed Alsoudani. Courtesy of the artist and Goff + Rosenthal. 


\section{Ungdomsoprør og islam}

I dag er befolkningen i de arabiske stater ekstremt ung set i forhold til aldersstrukturen: $60 \%$ af den totale befolkning er under 25 år gammel!9 Samtidig har unge utrolig svært ved at gøre deres stemme hørt i samfundet. Patriarkalske og konservative normer bremser meddelagtighed og forandring. Arbejdsmarkedet er desuden svagt. Ungdomsarbejdsløsheden er næsten dobbelt så høj som gennemsnittet for den $\varnothing$ vrige verden..$^{\text {Io }} \emptyset$ konomisk selvstændighed er dermed en svært opfyldelig drøm for millioner af drenge og piger. Den religiøse fundamentalisme er en af de få velbefærdede veje, som findes for de unge til at udtrykke deres frustration.

Den politiske islamisme i vor tid er dog ikke én, men mange forskellige bevægelser. Nogle er lukkede sekter, andre har mere åbne strukturer. Den historiske baggrund og sociale base varierer. Diskurs, retorik og ydre attributter ligner hinanden fra et land til et andet og fra en bevægelse til en anden. Dette giver en illusion af enhed og enighed. Men i den arabiske prosalitteratur kan konflikterne ses bag facaden. ${ }^{\text {II }}$

I løbet af 1900-tallets sidste decennier voksede en ungdomsgeneration frem i Egypten, for hvem islamisk ekstremisme indebar en ungdomsrevolte, en måde at kanalisere iboende oprørskhed ud på og en protest mod familie og samfund. Processen er på flere måder parallel til ungdomsoprøret i Europa, men med andre attributter og et anderledes resultat. Et belæg for denne tese er den selvbiografi, som for nogle år siden under en vis opmærksomhed publiceredes af et tidligere medlem af al-Jamma al-islamiyya [al-Gama'a al-islamiyya] under den provokerende titel Verden er skønnere end Paradiset (al-Dunya ajmal min al-janna). ${ }^{\mathrm{I2}}$ Bogen er blevet beskrevet som det "bedste indblik i den islamiske ungdomskultur", man kan finde i den arabiske litteratur lige nu. ${ }^{13}$ Undertitlen på omslaget, "en egyptisk fundamentalists livshistorie", fortæller tydeligt læseren, hvad bogen drejer sig om, og hvordan den skal forstås: fortællingen om forfatteren Khalid al-Barris oplevelser som sektmedlem skal læses som fakta, ikke fiktion.

I den samtidige arabiske roman spiller den islamiske aktivist ofte en forventet rolle, som ender med en ond, pludselig død: den hævnlystne student Taha i Yacoubians hus skydes ihjel under et attentat mod en øverstbefalende politiofficer; flykaprerne i Turki al-Hamads Paradisets vind (Rih al-janna, 2005) flyver ind i World Trade Center. Samme typiske terroristfortælling dominerer i medierne. Det glemmes, at afhopperne fra sekterne er langt flere end de som bliver tilbage, måske fordi denne sandhed ikke er kompatibel med "krigen mod terrorismen", eller fordi fundamentalisten skildret som bodfærdig stakkel ikke er politisk korrekt.

Hiba i Azazil foreslår i den politiske allegoris indirekte form, at alternativet trods alt findes og er muligt. Den selvbiografiske roman i Egypten indeholder også eksempler på frigørelsesfortællinger fra tidligere unge fundamentalister, som går på tværs af stereotypen: Forfatteren Miral al-Tahawi var i begyndelsen af 1990'erne medlem af den islamistiske studenterbevægelse og fuldstændig tilsløret. I Den blå aubergine (al-Badhinjana al-zarqa', 1998, dansk overs. 2006) hedder hendes alter ego Nada, en ung kvinde som studerer arabisk litteratur på et af Kairos universiteter. Nada er 
aktivist i den islamiske bevægelse. Hun viser ingen dele af sin krop offentligt. Sløret dækker ansigtet, handsker dækker hænderne og et klædningsstykke helt ned til fødderne dækker resten af kroppen. I bogen følger vi hendes indre kamp og søgen efter en voksenidentitet. Hun angribes af tvivl. Den religiøse ideologi skjuler autoritære strukturer og kønsundertrykkelse, mærker hun. Til trods for sin retfærdighedspatos og sit egalitære budskab er bevægelsen en streng og hierarkisk sekt. Nada gennemgår en indre udvikling og bryder ud.

\section{Farlige spørgsmål}

Fortællingen om Nada er som sagt selvbiografisk. I den virkelige verden er forfatterens erfaring med at forlade sekten slet ikke unik. Der er historien snarere typisk. Man kan af gode grunde tale om en generationsoplevelse. ${ }^{14}$ Khalid al-Barri siger udtrykkeligt i sin dokumentarversion, at hans historie ikke er speciel: "Jeg er bare én person ud af alle de hundredtusinder, som engang har været 'aktivister' i geleddet hos en eller anden islamisk organisation." ${ }^{15}$

Men i bøgernes verden dominerer andre billeder stadig. Den egyptiske selvbiografiske litteratur har i lang tid været fuld af opbyggelige fortællinger skrevet af frelste, som fortæller om deres frelse, hvad enten det drejer sig om almindelige mennesker, som kommer til indsigt om den rette vej - som i flere værker af tv-kvinden Kariman Hamza - eller sheiker fra al-Azhar, som fortæller om Guds vilje og nåde, som imamen Abd al-Halim Mahmud eller prædikanten Muhammad Mutwalli alSharawi i deres respektive værker. ${ }^{16}$ Genren er næsten uudtømmelig. Også mere eller mindre militante kvinder og mænd fra forbudte organisationer har i selvbiografiens form forklaret for sig selv og verden, hvorfor islam er løsningen på alle samfundsproblemer, ofte med den politiske forfølgelse og fængselscellen som dramatisk ramme. ${ }^{17}$ Derimod er det mere sjældent med historier om mennesker, som har brudt med islam og er blevet sekulære. I forhold til teksternes antal er afhoppernes bekendelser en klar minoritet.

En forklaring er, at der ofte er en pris at betale for den, som offentligt tager afstand fra religionens vej i Mellemøsten. Miral al-Tahawi blev stemplet som frafalden og vantro af sine tidligere kammerater efter publikationen af Den blå aubergine på trods af, at teksten præsenterer sig som en roman; denne indirekte trussel mod hendes liv blev betegnende nok fremført på websitet IslamOnline. ${ }^{18}$ Yusuf Zaydan løser listigt dette problem - at stille farlige spørgsmål og alligevel ikke træde nogen for direkte over tæerne - $\mathrm{i}$ kraft af den historiske fiktions forebyggende form samt ombytningen af religiøse roller: fanatiske kristne i stedet for fanatiske muslimer. Næsten ingen har været modig nok til at skrive afhopperens bekendelser uden beskyttelsesnet eller nogen form for maske. Dette gør Verden er skønnere end Paradiset til en speciel bog - og forfatteren til en modig mand. At Khalid al-Barri turde og kunne beror naturligvis på, at den radikale bevægelse, han forlod, også er en svoren fjende af det moderate islam og det egyptiske regime.

Organisationen al-Jamaa al-islamiyya stiftedes i 1970'erne i studenterkredse. Den var fortaler for væbnet kamp mod de herskende i samfundet, eftersom disse ikke styrede efter den religiøse lov. Dermed var de at sidestille med vantro og af- 
gudsdyrkere - ifølge Koranen: "De, der ikke dømmer efter det, som Gud har sendt ned, er de vantro" (Kor 5:44). Ligesom Profeten Muhammed og den første generation af muslimer, al-salaf, havde bekæmpet sine modstandere med vold, burde fromme muslimer i dag ty til våben mod deres tids gudsfornægtere med det formål at (gen)-oprette den islamiske stat - sådan lød logikken.

\section{Sayyid Qutb den lille}

Første gang, vi møder Khalid i hans fortælling, befinder han sig på en fodboldbane. Året er 1986, og han er fjorten år gammel. Stedet er hjembyen Assiut i øvre Egypten, som netop da er vidne til et udbrud af politisk vold. På fodboldbanen blandt de unge teenage-drenge er medlemmerne i al-Jamaa al-islamiyya helte. "Brødrene" er seje forbilleder og idoler for ungdommen. En ven lover Khalid at låne ham en motorcykelkæde, som han vil kunne bruge, hvis der bliver slagsmål. Det bliver der ofte, eftersom Khalid og hans venner plages af en ældre fyr på gaden, som er større og stærkere og leder af en bande, som drikker sprut, ryger hash og har prøvet sex. Med en motorcykelkæde er det lettere at forsvare sig...

Fodbold er Khalids favoritbeskæftigelse. Ellers kan han bedst lide at se film og fjernsyn og lytte til musik, eksempelvis den syriske kunstner Mayada al-Hanawi. Faren er gammel nasserist og familien velstillet middelklasse: den ejer to udlejningshuse og bor selv i det ene. Khalid har gået i en fin skole, Franciskanernonnernes skole, hvor har han lært kristne sange (!), og at det er ikke er pænt at lyve. Nu skal han snart begynde på gymnasiet. Materielt har han det godt, og hans karakterer er fine. Men militant islam lokker med et mere spændende liv.

Sociale uretfærdigheder beskrives ofte som en typisk grobund for religiøs fundamentalisme og ekstremisme. Men faktum er, at mange, omend ikke de fleste, af de egyptiske islamister kommer fra middelklassebaggrund. Da sociologen Saad Eddin Ibrahim og hans medhjælpere i slutningen af 1970'erne under stort besvær gennemførte en interviewundersøgelse med fængslede medlemmer fra militante islamiske grupper, fandt de, at den gennemsnitlige aktivist var en ung mand i tyveårsalderen, fra landsbyen eller en mindre by, middelklasse, højtuddannet (ofte inden for naturvidenskab eller teknik) og socialt mobil på vej opad. I stedet for det forventede abnorme og marginaliserede fjols viste undersøgelsen, at den typiske "terrorist" i mange henseender var en forbilledlig ung egypter. Hvis han på nogen måde var unormal, var det, fordi han var signifikant mere opvakt og begavet end sine jævnaldrende. ${ }^{19}$

Denne medlemsprofil stemmer fint overens med billedet af hovedpersonen i Verden er skønnere end Paradiset. Spænding, mening og magt pakket ind som verdensforbedrende idealisme snarere end vrede over egne økonomiske forhold er drivkræfterne for ham. Moralsk indignation og vrede over uretfærdigheder spiller naturligvis også en stor rolle, ikke mindst retorisk. Han er ung og engageret, men lidelsen er ikke personlig og miseren ikke privat. Hvis analogien til ungdomsoprøret i Europa holder, kan man her sammenligne med den radikale venstrefløj og dens militante medlemmer, som næppe heller var pjalteproletarer.

Khalids vej ind i bevægelsen er bønnens og studiecirklens. Han begynder at bede 
i moskéen og starter i en studiecirkel hos en sheik, som giver lektioner i islamisk lov samt profetens liv og traditioner. Forfatteren beskriver det hele som en initieringsproces i tre skridt:

Først er han sympatisør og undervises i almene forskrifter efter den fundamentalistiske lære, som blandt andet forbyder musik og underholdning på tv (første forsagelse).

Siden, efter et år, antages han som rigtigt medlem og skal lære, at jihad og hisba (afstraffelse af den som ikke følger de religiøse regler) er lige så vigtige som bøn, almisser og faste for den troende. Nu er det på tide at ændre tøjstil og sprog; skæg og galabiyya ned til fødderne er det påkrævede; jeans er djævlens tøj (anden forsagelse).

Tredje skridt i initieringsprocessen er studiet af politiske traktater som "Vedtægter for det islamiske arbejde" og forskellige skrifter, som prædiker oprør mod staten. Propagandamateriale fra krigen i Afghanistan mod russerne styrker moralen og følelsen af at kæmpe for en retfærdig sag. Man sammenligner sin egen organisations linje med andre militante gruppers argumentation og kritiserer deres fejl i spørgsmål som "hvornår må man dræbe?" og "hvem må man dræbe i islams navn?" Al-Jamaa al-islamiyya er avantgarden og Muslimske brødre er alt for eftergivende overfor regimet! I dette stadium indebærer indoktrineringen, at organisationen overtager medlemmets liv totalt og begrænser dets omgang udadtil, inklusiv slægtninge og nær familie (tredje forsagelse):

4 Brødrene bad eksplicit individet om at begrænse sin omgang med ikke-frelste muslimske jævnaldrende, eftersom "mennesket tilhører sin vens religion, og så må hver og én søge efter en passende ven" (tradition fra Dawud al-Tirmidhi), ligesom man begærede at aktivisten skulle klippe båndene til alle ikke-muslimer, eftersom "Du vil ikke finde, at folk, der tror på Gud og den yderste dag, elsker dem, der sætter sig op imod Gud og Hans udsending, ikke engang, hvis det skulle være deres fædre og sønner eller brødre eller stammefolk" (Kor 58: 22).

Det som, ifølge ham selv og set retrospektivt, får Khalid al-Barri til at gå hele vejen og acceptere alle forskrifter og regler om tøj og udseende, omgangskreds og venner, ja, også bordskik og opførsel (inklusiv føddernes rækkefølge, når man træder ind i moskéen eller går på toilettet), er, at han føler sig speciel og udvalgt. Takket være bevægelsen bliver han nogen, en indsat person med en opgave og et kald.

Hans konkrete opgave bliver at hverve nye medlemmer og agitere. Takket være sin gode hukommelse og sin intelligens er han snart en mester i doxaen og får kælenavnet Sayyid Qutb den lille efter idolet, hvis skrifter han lærer sig udenad, og hvis stil han imiterer. At strides på ord og debattere bliver en favoritbeskæftigelse. Dogmatismen giver ham både social ret og effektive måder at protestere mod voksenverdenens dominans på. Han er bare en teenager, men kan alligevel latterliggøre hvem som helst ved hjælp af citater og argumenter fra de islamiske autoriteter. Det er et tidens tegn og et fænomen, som ikke alle synes om: den ærefrygtindgydende sheik Kishk høres vredt protestere mod ungdommens frækhed i en af sine prædikener fra 1981: "Nu for tiden må en stor muslimsk prædikant i halvfjerdsårsalderen 
regne med at blive afbrudt af en grønskolling i puberteten, som har læst nogle ord eller sider af Ibn Taymiyya eller Ibn Abd al-Wahbag og udgiver sig for at være en troens vogter! Hvilken farce..." ${ }^{20}$

Khalid udses til leder, emir, for alle gymnasiaster i byen. Da han tvinges til at skifte skole, anklaget for agitation, føler han sig som en forfulgt helt. Prestige og respekt præger omgivelsernes reaktion. Mange er bange for gruppen, han tilhører, og den vold, som den udsætter de anderledestænkende og forhadte for, eksempelvis homoseksuelle elever. Det er let at være sej, når man har himlen på sin side, og det har Khalid. Sekten giver ham svar på alle eksistentielle spørgsmål, skænker tryghed og fællesskab, prestige og status.

Desuden, reflekterer afhopperen i sin bog, "åbnede al-Jamaa al-islamiyya nye muligheder for oprør mod den konservative og borgerlige opdragelse, som jeg havde fået i Franciskanernonnernes skole og derhjemme og fik mig til at fordybe mig i forskellige samfundsklassers liv." ${ }^{2 r}$ Solidaritet med de fattige og had mod systemet - mønstret genkendes.

\section{Opvågningen}

Det er fint så længe det varer, men jorden er trods alt ikke Paradiset. Efterhånden som han bliver ældre og klogere, begynder tvivlen at smyge sig ind. Hierarkiet skjuler dobbeltmoral og egoisme; ikke alle lever som de prædiker. Volden mod almindelige mennesker er planløs og grum, trakasserierne meningsløse. Læren havner i konflikt med de indre behov, ikke mindst de seksuelle drifter. Er det følelserne, der er noget galt med, eller er det forbuddene? Da Khalid begynder at studere og agitere på universitetet, er vi nået frem til år 1991. Den 7. oktober bliver han arresteret i hjemmet, 19 år gammel. På det tidspunkt har han tilhørt den islamiske bevægelse i fem år. Han føres til Liman Tura-fængslet i Kairo, hvor han kommer til at sidde uden rettergang, indtil han bliver løsladt godt to måneder senere.

Fængselsopholdet bliver et vendepunkt. Frihedsberøvelsen og den dårlige behandling er ikke noget, han vil opleve igen, og desuden mobbes han af brødrene i fængslet, som håner ham, fordi han skriver breve til familien og forsøger at studere for ikke at dumpe i sine medicinstudier. Han føler sig fremmedgjort fra de tidligere kammerater. Den fundamentalistiske overbevisning til trods synes han pludseligt, at "denne verden er skønnere end Paradiset og menneskets sjæl hænger i næbbet på frihedens fugl.".22

Verden er skønnere end Paradiset afsluttes med et kapitel, hvor afhopperen fortæller om sin vej ud af sekten. Det føltes som at vågne op af en drøm, skriver han. Fra ørn blev han spurv igen. For Khalid al-Barri tog det fem år at finde en anden måde at leve på og en ny filosofi. Afhopningen indebar en personlig krise, et identitetstab og en uendelighed af grublen og selvransagelse. Han beskriver det som en lang proces. Den begyndte med, at han holdt op med at deltage i bevægelsens aktiviteter, dernæst opgav han langsomt ideologien og trossætningerne, først derefter vanerne (bønnen og litteraturen), inden han til sidst kunne skaffe sig nye vaner og tankebaner. En del af afprogrammeringen var at starte med at læse skønlitteratur igen og supplere med selvbiografier om andre tvivlere til inspiration og trøst, lige- 
som han også afprøvede forskellige livsstile som f.eks. den vegetariske og forskellige verdslige fornøjelser, inklusiv pornofilm.

Billedet af afhopperens situation og sekttilhørsforholdets psykologi i denne arabiske bog minder mig stærkt om den beskrivelse, som Anders Haag, engang medlem af Hare Krishna-kollektivet uden for Stockholm, giver i sin aktuelle svenske bekendelse: Att vinna en tro och förlora sig själv (2009). I det globaliserede samfund synes alle sekter at være organisk ens i forhold til hinanden; det religiøse udenværk er det, som adskiller.

\section{Oversat af Peter Bo Andersen}

\section{Noter}

I En illustration af Yusuf Zaydans tidligere ubemærkethed som litterær figur er, at hans navn mangler på den liste over cirka hundrede egyptiske skønlitterære forfattere og kritikere, som Richard Jacquemond præsenterer i sit historiesociologisk indrettede studie fra 2008: Conscience of the Nation. "Appendix 1: Egyptian Writers and Critics", s. 237-289.

2 Azazil/Azazel/Asasel er et navn, som forekommer i såvel jødisk som kristen og islamisk mytologi, en falden engel eller dæmon som ofte forbindes med helvede og Satan. I Biblen er Azazel nævnt i Tredje Mosebog (Leviticus) 16:8 ff.

3 Zaydān, 2009. Appendiks s. 371-380, sammenlagt ti sort-hvide billeder.

4 Repræsentanter for den koptiske kirke har protesteret mod romanen, som de mener giver et forløjet billede af den historiske virkelighed i al almindelighed og biskop Kyrillus' rolle i særdeleshed. For et indblik i debatten, se eksempelvis Bayoumi, 2008 eller Wazen, 2009.

5 For en længere diskussion af dette emne, se Rooke, 2008.

6 Navnene på dommerne skifter hvert år og er anonyme, indtil den "korte liste" over de nominerede værker er blevet offentliggjort. 2008-2009 bestod juryen af fem personer: Yumna el Eid (akademiker, Libanon), Rasheed el-Enany (akademiker, Egypten/England), Hartmut Fähndrich (oversætter, Tyskland), Muhammad al Murr (forfatter, Forenede Arabiske Emirater) og Fakhri Saleh (kritiker, Jordan).

7 Davies, 2009.

8 Al-Hakims stykke fra 1960, Den tvivlrådige sultan (al-Ṣultān al-Hā’ir), er udgivet i engelsk oversættelse som "The Sultan's Dilemma" (Tawfiq Hakim, The Fate of the Cockroach and Other Plays, 1973, ny udgave 1994) og blev for nyligt spillet i en nyoversat svensk version af Kungliga Dramatiska Teatern i Stockholm, også der med titlen Sultanens dilemma.

9 Arab Human Development Report 2009, “The Report in Brief", s. 3.

Io Ibid., s. 10.

II Selv professionelle islamologer har syndet, når det gælder forenklingen af den politiske islamisme, mener Philip Halldén i sin bog om den "jihad-salafistiske strømning" og hvad den indebærer: "I det generelle studie af islamiske bevægelser (...) og ved at forskellige islamiske bevægelser i visse sammenhænge er blevet fremstillet som om de var ligeværdige udtryk for én og samme ideologi, har beredskabet også været temmelig dårligt i forhold til at forklare de forskelligheder og modsætninger som faktisk findes mellem disse bevægelser." Halldén, 2007, s. 10. I kapitlet "Begrebet salafism" (s. 11-15) gives en kort introduktion til problematikken. 
I2 al-Barrī, 2006. Teksten publiceredes først som en artikelserie i den libanesiske avis al-Naha med begyndelse i 1999, og med tiden færdiggjordes den af forfatteren til en bog, som udkom i Libanon 2001. Første egyptiske udgave: 2006.

I3 Naggar, 2006.

I4 En af al-Tahawis kolleger og nære venner i Kairo, Afaf al-Sayyid (f. 1963), har eksempelvis gennemgået samme udvikling fra radikal islamist til sekulær feminist. Hun fortæller dele af sin livshistorie i novelleantologien Figli del Nilo (Prevedello, 2006, s. 151-154).

I5 al-Barri, op. cit., s. 5. "Aktivist" er min oversættelse af det arabiske multazim.

I6 Kariman Hamza: Min vej fra utilsløret til tilsløret (Riḥlatī min al-sufūr ilā al-hijāb, Kairo 1981); Muhammad Mutwallī al-Sha 'rāwī: Mit liv fra Daqadus til minister (Hayātī min Daqādūs ilā alwizāra, Alexandria 1992; ); 'Abd al-Halīm Mahmūd, Gudvære lovet! Dette er mit liv (al-Hamdu li-1llāhi hādhihi Hayātī, Kairo 1976). For en indgående diskussion af Karimān Hamza og hendes selvbiografi, se Malti-Douglas, 2001. For en beskrivelse af Mahmuds bog, se Rooke, 1997, s. 93-97.

I7 Et par eksempler er de politiske memoirer af den kvindelige islamist, Zaynab al-Ghazālī (1917-2005): Dage af mit liv (Ayyām min hayātī, Kairo 1987), også oversat til engelsk som The Return of the Pharaoh (2006), og selvbiografien, Glimt fra mit liv (Lamaḥāt min ḥayātī, 3 vol., Beirut 1985-1988) af Najīb al-Kīlānī (1931-1995), læge, forfatter og medlem af det Muslimske broderskab siden ungdommen.

I8 Interview med forfatteren, Faqus, 2002-11-02.

I9 Ibrahim, 1980, se især s. 440.

20 Dele af Abd al-Hamid Kishks prædikener findes oversat og kommenterede af Kepel, 1986, s. $178 \mathrm{ff}$. Citatet er hentet fra side 179 og oversat fra engelsk af mig.

2I Al-Barri, op.cit. s. 59.

22 Ibid., s. 119.

\section{Litteratur}

Arab Human Development Report 2009. Challenges to Human Security in the Arab Countries. "The Report in Bief”, 2009. New York: the United Nations Development Programme. Tilgængelig elektronisk: http://www.arab-hdr.org/publications/contents/2009/execsummary-e.pdf al-Barrī, Khālid (2006): al-Dunyā ajmal min al-janna. Kairo: Merit. Første oplag 2001, Beirut: Dār al-nahār.

Bayoumi, Amr (2008): "Author of 'Azazil' Confirms the Novel Events Are Real; Requests Father Bishoi to Re-read it", Almasry Alyoum, 2008-07-26, http://www.almasry-alyoum.com/article2. aspx?ArticleID=114837 (besøgt 2009-08-02).

Davies, Hannah (2009): "Egyptian author wins Arabic fiction prize", The Bookseller, 2009-03-17, http://www.thebookseller.com/news/79951-egyptian-author-wins-arabic-fiction-prize.html.rss (besøgt 2009-07-30).

Haag, Anders (2009): Att vinna en tro och förlora sig själv. Om livet i sekter och karismatiska grupper. Stockholm: Natur och Kultur.

Halldén, Philip (2007): Jihad-orienterad salafism på internet, Studier av inter-religiösa relationer 38. Uppsala: Swedish Science Press.

Ibrahim, Saad Eddin (1980): “Anatomy of Egypt's Militant Islamic Groups: Methodological Note and Preliminary Findings”, i International Journal of Middle East Studies, 12, s. 423-453. 
Kairo: American University Press.

Kepel, Gilles (1986): Muslim Extremism in Egypt: The Prophet and Pharaoh. Berkeley: University of California Press.

Koranen (1979), Oversat fra arabisk af Ellen Wulff. København: Forlaget Vandkunsten. 2006.

Koranens budskap (1998), I en svensk tolkning af Muhammed Knut Bernström med kommentarer af Muhammad Asad. Stockholm: Proprius.

Malti-Douglas, Fedwa (2001): Medicines of the Soul. Female Bodies and Sacred Geographies in Transnational Islam. Berkeley: University of California Press.

Naggar, Mona (2006): “Destination Paradise”, Signandsight.com, 2006-11-23: http://www.signandsight.com/features/1057.html (besøgt 2009-08-01). Artiklen blev først publiceret i Neue Züricher Zeitung, 2006-11-11.

Prevedello, Francesca (red.) (2006): Figli del Nilo. Undici scrittori egiziani si raccontano. Messina: Mesogea.

Rooke, Tetz: "The Emergence of the Arabic Bestseller - Arabic Fiction and World Literature", paper til det ottende EURAMAL, Uppsala 9.-14. juni, 2008 (under udgivelse).

Rooke, Tetz (1997): "In My Childhood". A Study of Arabic Autobiography. Stockholm: Stockholm University.

al-Tahāwī, Mīrāl (2000): al-Bādhinjāna al-zarqā', 4 ed.. Beirut: Dār al-adāb.

Zaydān, Yūsūf (2009): Azāzīl, 5. oplag. Kairo: Dār al-Shurūq.

Wazen, Abdo (2009): “The Anger over Azazeel”, Banipal, nr. 34, s. 70 - 74. 